\title{
OS ESTUDANTES AFRICANOS NO BRASIL NA PERSPECTIVA DA TEORIA CRÍTICA DOS DIREITOS HUMANOS
}

\author{
Thula Rafaela de Oliveira Pires ${ }^{1}$ \\ Vanessa Oliveira Batista Berner ${ }^{2}$ \\ Julia Monteath de França ${ }^{3}$
}

\begin{abstract}
Resumo
A proposta deste artigo é analisar a situação dos estudantes africanos no Brasil à luz da Teoria do Reconhecimento de Honneth e de um conceito emancipatório dos direitos humanos. A partir das principais contribuições teóricas acerca do debate sobre reconhecimento pretende-se consolidar uma concepção dos direitos humanos como resistência e emancipação. Através de idéias como 'identidade' e 'autenticidade', busca-se afirmar a singularidade do sujeito e confrontar o universalismo abstrato dos direitos humanos, no que diz respeito à questão migratória. O reconhecimento enquanto necessidade humana vital ressalta a importância do Outro para a conformação sadia das Identidades. Diante da relação inexorável entre identidade e reconhecimento, destaca-se a proposta de Axel Honneth para uma vinculação mais estreita entre teoria do reconhecimento e direito. A partir da constatação de que os seres humanos, e nesse artigo especificamente os imigrantes, não podem se comportar de maneira neutra e passiva em relação às ofensas sociais, maus tratos físicos ou à privação de direitos, os direitos humanos deixam de se constituírem em um eficiente depósito de rancor, dando lugar a um laboratório de resistência.
\end{abstract}

Palavras Chaves: Direitos Humanos; Imigração; Africanos; Brasil; Teoria do Reconhecimento.

\section{INTRODUÇÃO}

No século XX a migração, que sempre foi um elemento básico da condição social, passou a refletir questões individuais e coletivas que colocam à prova o próprio funcionamento do

\footnotetext{
${ }^{1}$ Doutora em Direito Constitucional e Teoria do Estado (PUC-Rio). Professora do Departamento de Direito (PUC-Rio). Pesquisadora do Laboratório de Direitos Humanos da UFRJ (LADIH/UFRJ) e do Núcleo de Estudos Constitucionais doDepartamento de Direito da PUC-Rio. E-mail: thula@puc-rio.

${ }^{2}$ Doutora em Direito (UFMG). Professora associada da Universidade Federal do Rio deJaneiro, na Faculdade Nacional de Direito. Coordenadora do Laboratório de DireitosHumanos da UFRJ (LADIH/UFRJ). Email:vanessabberner@gmail.com.

3 Graduada em Ciências Sociais (bacharelado e licenciatura) e Mestre em Economia Política Internacional (UFRJ). Pesquisadora do Laboratório de Direitos Humanos da UFRJ (LADIH/UFRJ). E-mail: julia_mfranca@yahoo.com.br
} 
Estado. A relação entre a migração e o fato de se pertencer a um determinado Estado é ambígua, pois tem-se, de um lado, o encorajamento para que o indivíduo exerça sua liberdade de locomoção, o que é um dado histórico que acompanha o conceito de domicílio desde a formação do Estado moderno; por outro lado, pertencer a um Estado significa manter também uma estreita conexão com o território e as pessoas sob controle de determinado poder estatal. A questão das migrações envolve, portanto, a perda tanto do vínculo do indivíduo com o Estado, quanto com sua comunidade política original. ${ }^{4}$

Entre as diversas categorias de imigrantes, tem-se os voluntários - aqueles que migram por vontade própria e tem um visto de trabalho concedido pelo país de destino; e os forçados aqueles que migram em função de circunstâncias desfavoráveis no país de origem e obtêm um estatuto de proteção concedido pelo país de destino: fogem de guerras, perseguições, etc. e tem sua condição resguardada por tratados internacionais.

Número significativo de imigrantes africanos que hoje estão no Brasil entra na condição de refugiados (imigrantes forçados) ou de estudantes (que não se encaixam exatamente na categoria de imigrante voluntário, por não terem um visto de trabalho, sendo estrangeiros com visto temporário). ${ }^{5}$ Estes últimos representam a maior parte dos estudantes que entram no Brasil pela via dos convênios PEC-G (graduação) e PEC-PG (Pós- graduação), ${ }^{6}$ oferecidos pelo Ministério das Relações Exteriores (MRE) em parceria com o Ministério da Educação (MEC). Tendo em vista a representatividade numérica desta categoria, o texto se aprofundará nas experiências destes imigrantes africanos.

A saída do lugar de origem e o distanciamento de suas raízes culturais, laços de afeto e pertencimento é apaziguada pela promessa de que encontrarão no país de acolhimento, pelo menos, o respeito aos direitos humanos. Na doutrina brasileira e estrangeira ${ }^{7}$ vigora com certa preponderância uma noção de direitos humanos como o conjunto de faculdades e instituições que, como reivindicações morais e políticas amplamente compartilhadas, concretizam as exigências da dignidade, liberdade e igualdade humana em uma comunidade historicamente situada. ${ }^{8}$

\footnotetext{
${ }^{4} \mathrm{O}$ processo de construção de identidade é necessariamente complexo e contínuo. $\mathrm{O}$ estar em um lugar ao qual, a princípio, não se pertence, acrescenta um fator que o complexifica ainda mais. Neste sentido, debates como o da identidade diaspórica e o do pertencimento a comunidades transnacionais se fazem fundamentais para se pensar o fenômeno como um todo. Para uma visão geral sobre a produção e o debate acerca do transnacionalismo, ver Guarnizo (2003), Guarnizo, Haller e Portes (2003), Vertovec (2003), Levitt e Glick Schiller (2004), Portes (2004) e Waldinger (2010).

${ }^{5}$ Até 2015, do total de 8.747 estudantes selecionados pelo PEC-G, 6.761 eram africanos, 1.939 da América vol.09, nº. 02, Rio de Janeiro, 2016. pp. 
Latina e Caribe e 47 da Ásia. Até 2013, do total de 9.900 estudantes selecionados pelo PEC-G e pelo PEC-PG, 6.630 eram africanos, 2.609 da América Latina e Caribe e 115 da Ásia. Fonte: http://www.dce.mre.gov.br/PEC/apresentacao.php, consultado em 17/12/2015.

${ }^{6}$ Ambos Programas de Estudantes-Convênio para estudantes do ensino superior oriundos de países em desenvolvimento da África, Ásia, América Latina e Caribe. O objetivo central é facilitar o intercâmbio e aproximar a experiência acadêmica ao trazer estes estudantes para realizar estudos no Brasil, seja $\mathrm{cm}$ foco na Graduação (PEC-G) ou na Pós-Graduação (PEC-PG).

${ }^{7}$ Nesse sentido, ver Comparato (1999); Mello (2004); Lafer (1998); Bobbio (1992). Para uma crítica à concepção hegemônico- ocidental da trajetória dos direitos humanos, ver: Villey (2007); Santos (2003); Piovesan (2006); Batista, Boiteux \& Pires (2009), Hunt (2009) Herrera Flores (2009) e Douzinas (2009).

${ }^{8}$ Alguns autores traçaram o processo histórico de afirmação dos direitos humanos, mas nem todos se impuseram a tarefa de defini- los. Celso D. de Albuquerque Mello (2004, pg. 813) ressalta as definições desenvolvidas por Perez Luño, Louis Henkin. De acordo com Perez Luño, chamamos de direitos humanos: "um conjunto de faculdades e instituiç̃es, que, em determinado momento histórico, concretiza as exigências da dignidade, a liberdade e a igualdade humana, as quais devem ser reconhecidas positivamente pelos ordenamentos jurídicos a nível nacional e internacional". Louis Henkin afirma que: "Direitos Humanos constituem um termo de uso comum mas não categoricamente definido. Esses direitos são concebidos de forma a incluir aquelas 'reivindicações 
Apesar de tratados como construções humanas contingentes, se impõe com certa carga de confiabilidade a crença de que tais direitos foram feitos para proteger todos os seres humanos ou, pelo menos, todos aqueles definidos em lei como seus destinatários. No entanto, depois das críticas de Hegel, Marx e Burke difunde-se a ideia de que a dogmática dos direitos humanos foi construída a partir de um Sujeito, que pode ser identificado com o homem branco, europeu, cristão, detentor dos meios de produção, heteronormativo e não portador de deficiência.

A partir dos dados referentes à situação dos africanos no Brasil, ${ }^{9}$ pretende-se refletir sobre a fruição de direitos permitida a esse grupo e os principais entraves para que sejam tratados com igual estima e consideração em relação a outros grupos. O discurso da universalização dos direitos humanos esbarra na mais rápida observação da situação de pessoas cujas características sociais e culturais destoam do padrão definido como próprio do Sujeito desses direitos.

A violação de direitos, desigualdade e desrespeito a que estão submetidos materializa os paradoxos gerados por uma noção de direitos humanos não comprometida com a emancipação de seres concretos e plurais e denuncia a falácia do discurso de sua universalidade. A proposta de universalização retórica mascara e naturaliza ${ }^{10}$ relações sociais de dominação, opressão e de sistemática ofensa à integridade, identidade, cultura e memória do Outro.

morais e políticas, que, no consenso contemporâneo, todo ser humano tem o dever de ter perante sua sociedade ou governo', reivindicações estas reconhecidas como 'de direito' e não apenas por amor, graça ou caridade.". Peces-Barba, define-os como: "faculdades que o Direito atribui a pessoas e aos grupos socais, expressão de suas necessidades relativas à vida, liberdade, igualdade, participação política, ou social ou a qualquer outro aspecto fundamental que afete o desenvolvimento integral das pessoas em uma comunidade de homens livres, exigindo o respeito ou a atuação dos demais homens, dos grupos sociais e do Estado, e com garantia dos poderes públicos para restabelecer seu exercício em caso de violação ou para realizar sua prestação". Para Dalmo Dallari (1998, pg.7) os direitos humanos seriam aqueles sem os quais a pessoa humana não conseguiria existir ou não seria capaz de desenvolver-se e de participar plenamente da vida.

No mesmo sentido, André de Carvalho Ramos (2002, pg.13) considera os direitos humanos aqueles cujo conteúdo é decisivamente constitutivo da dignidade humana em determinado contexto histórico.

Bobbio (1992, pg. 5) os define como direitos cujo reconhecimento é condição necessária para o aperfeiçoamento da pessoa humana ou para o desenvolvimento da civilização.

Flávia Piovesan (2007, pg. 8) destaca os conceitos de Carlos Santiago Nino, Hannah Arendt e Joaquín Herrera Flores. Nino considera que "os direitos humanos são uma construção consciente vocacionada a assegurar a dignidade humana e a evitar sofrimentos, em face da persistente brutalidade humana." Arendt afirma que "os direitos humanos não são um dado, mas um construído, uma invenção humana, em constante processo de construção e reconstrução." Herrera Flores os entende como um construído axiológico, a partir de um espaço simbólico de luta e ação social. Nesse sentido os "direitos humanos compõem uma racionalidade de resistência, na medida em que traduzem processos que abrem e consolidam espaços de luta pela dignidade humana".

A visão crítica de Herrera Flores acrescenta às anteriores uma natureza emancipatória e, por esse motivo, Flores e Costas Douzinas representam o marco teórico deste artigo para a defesa dos direitos humanos.

${ }^{9}$ A elaboração deste trabalho não compreende uma pesquisa de campo acerca dos africanos, pois a proposta que deu origem ao presente artigo foi trazer a discussão teórica sobre os dados já disponíveis em outras fontes, como os dados estatísticos, teses, dissertações e investigação in loco de outros autores.

${ }^{10}$ Trabalhando relações de dominação pessoal e impessoal a partir de Bourdieu, Jessé Souza afirma "Todas as sociedades, modernas ou pré-modernas, produzem mecanismos específicos de 'des-conhecimento' que vol.09, nº. 02, Rio de Janeiro, 2016. pp. 
permitem, ao refratar a percepção da realidade imediata, que as relações sociais de dominação ganhem autonomia própria ao 'aparecerem' como naturais e indiscutíveis. 
Para que os direitos humanos sejam utilizados para desafiar a noção de universalidade dos valores ocidentais, promovendo outros valores decorrentes de outras experiências (de gênero, cultura, classe, raça, religião, sexualidade, cidadania), pretende-se, através da Teoria do Reconhecimento, reabilitar sua força libertadora e contra-hegemônica para que eles, de fato, se imponham como mecanismo de resistência a todas as formas de opressão. ${ }^{11}$

Na próxima seção faremos uma breve contextualização da Teoria do Reconhecimento, referência para a perspectiva aqui proposta dos direitos humanos, apresentando alguns conceitos fundamentais para compreendê- la - a saber, o de identidade, de autenticidade e de reconhecimento - bem como destacando a referência de Axel Honneth e sua teoria das três esferas do reconhecimento. A partir deste marco teórico, apresentaremos na terceira seção nossa leitura sobre a questão da imigração africana no Brasil, em particular das experiências destes imigrantes através do intercâmbio via convênio PEC-G e PEC-PG, destacando as dificuldades vividas por eles no processo de integração em uma "terra do outro". Finalmente, na quarta seção, defenderemos que através da perspectiva aqui proposta, é possivel encarar questões de direitos humanos como essas vivenciadas diariamente por imigrantes não como uma forma de violência de reação passiva, mas como uma forma de resposta às violações através da resistência.

\section{TEORIA DO RECONHECIMENTO E O DIREITO}

Passaremos agora a apresentar a Teoria do Reconhcimento, particularmente através da perspectiva de Axel Honneth, referência a partir da qual pretendemos desenvolver neste artigo não apenas a leitura das lutas relacionadas aos direitos humanos, de maneira mais geral, mas também a experiência concreta de imigrantes africanos vivendo no Brasil, com especial foco na experiência daqueles que vêm para fazer intercâmbio via convênios oficiais. Para tanto apresentaremos em um primeiro momento três conceitos fundamentais para compreender a Teoria o Reconhecimento: identidade, autenticidade e reconhecimento. A seguir apresentaremos a obra de Honneth, em particular sua teoria das três esferas do reconhecimento.

Toda sociedade, seja moderna ou pré-moderna, tende a naturalizar relações sociais que são contingentes e constituídas socialmente. A forma que essa ‘illusio' assume, no entanto é histórica e mutável. Bourdieu tende a chamar esse efeito encobridor e mascarador de 'capital simbólico'.” (SOUZA, 2007, pg. 62). Para uma melhor análise dos desafios do enfrentamento desse "capital simbólico", ver (SOUZA, 2007, pgs. 55-93)

${ }^{11}$ Por influência de Douzinas (2009, pg. 294), o trabalho se apóia no conceito de opressão como negação do vol.09, nº. 02, Rio de Janeiro, 2016. pp. 
autodesenvolvimento, defendido por Íris Young. As suas formas mais evidentes são a exploração econômica, a marginalização social, a inutilidade cultural e a violência. Nas palavras de Douzinas (2009, pg. 96): “a opressão nega a capacidade das pessoas de decidir qual é o melhor projeto de vida para elas e as priva dos meios necessários para levá-lo adiante. Não permite a suas vítimas viverem conforme seus desejos e desenvolverem seu potencial, além de impedir a realização de suas aspirações e capacidades”. 


\section{Identidade, autenticidade e reconhecimento}

A análise da situação dos imigrantes africanos no Brasil será empreendida a partir da Teoria do Reconhecimento de Axel Honneth e da concepção intercultural de direitos humanos defendida por Herrera Flores e Costas Douzinas. Antes de desenvolver as reflexões que o objeto suscita, é necessário determinar o entendimento acerca das idéias de identidade, autenticidade e reconhecimento que norteiam o trabalho.

Assim como Taylor (2001) entende-se a identidade como algo equivalente à interpretação que uma pessoa faz de si mesma e das características fundamentais que a definem como ser humano. ${ }^{12} \mathrm{~A}$ identidade é entendida a partir da relação que se estabelece com a noção de virtude e bem, dentro de uma determinada hierarquia moral (MATTOS, 2007).

Do ponto de vista teórico, as experiências da diferença e do encontro com o Outro são sempre enriquecedoras, pois elas representam a própria condição de emergência da identidade (SEMPRINI, 1999). Se no momento da interação um indivíduo sente que sua autoimagem retransmitida pelo outro é uma imagem desvalorizante, discriminatória ou agressiva, esta experiência pode perturbar o sujeito e instalar uma dúvida sobre o seu real valor e a importância social das metas que estabeleceu para si mesmo.

Habermas (1990) entende por 'identidade bem-sucedida'13 a capacidade peculiar de sujeitos capazes de falar e agir, de permanecerem idênticos a si mesmos, inclusive nas mudanças profundas da estrutura da personalidade, com as quais eles reagem a situações contraditórias.

A íntima conexão entre identidade e reconhecimento advém da constatação de que este interfere decisivamente na conformação da primeira. Os indivíduos só se transformam em agentes humanos plenos, capazes de compreenderem a si mesmos e, portanto, de definir sua identidade, na relação com o outro, por meio da linguagem. ${ }^{14}$ É na interação com o outro que o sujeito se constitui. A identidade é formada pela compreensão de si mesmo e dos que estão à volta, por meio da aquisição de significações compartilhadas. ${ }^{12} \mathrm{O}$ autor demonstra a correlação entre identidade e moralidade. Segundo interpretação de Patrícia Mattos
(2007, pg. 51), perceber a relação entre identidade e moralidade é superar o 'naturalismo' que domina a atitude
natural da vida cotidiana. Naturalismo esse responsável pela noção objetificada de self e pela defesa das
instituições modernas neutras, baseadas em critérios 'meritocráticos' e 'igualitários'.
${ }^{13}$ Para Habermas, a formação da identidade ocorre da seguinte maneira (1990, pgs. 78-81): uma criança adquire
uma 'identidade natural', estabelecendo limites entre o seu corpo e o ambiente que a circunda. Essa identidade
natural só será substituída por uma identidade constituída por papéis e mediatizada simbolicamente quando o
indivíduo for capaz de se localizar em seu mundo social de vida, incorporando as universalidades simbólicas
dos papéis menos fundamentais do seu ambiente familiar e as normas de ação de grupos mais amplos. Nesse
estágio, o indivíduo passa a ter a capacidade de se referir a si mesmo através da reflexão, isto é, o indivíduo
entra em comunicação com um outro Eu, de tal modo que ambos podem conhecer-se e reconhecer-se
vol.09, no no ${ }^{\circ}$. 02, Rio de Janeiro, 2016. pp. 
reciprocamente como Eus. No adulto a identidade do Eu se confirma na capacidade de construir novas identidades, "integrando nelas as identidades superadas e organizando a si mesmo e às próprias interações numa biografia inconfundível”. Nessa fase, podemos ver confirmada a afirmação hegeliana de que o Eu é Universal Absoluto e, ao mesmo tempo, singularização absoluta.

${ }^{14}$ Taylor parece seguir a concepção de linguagem definida pelo expressivismo. Esse modelo de pensamento, que tem como grande teórico Herder, entende a linguagem como um meio ao qual estamos imersos e que nos constitui, sendo reducionista qualquer concepção que a entenda como algo que opera entre nós e o mundo objetivo, conforme postula o naturalismo. Para os 
Para melhor explorar a relação entre identidade e reconhecimento, é necessário caracterizar a ideia de autenticidade. $\mathrm{O}$ ideal de autenticidade ${ }^{15}$ conclama o indivíduo a descobrir seu modo singular de ser: cada indivíduo é diferente e original, e é essa originalidade que determina como ele deve viver (TAYLOR, 1997).

A liberdade moderna e a autonomia exigem que os sujeitos se centrem em si mesmos. Essa auto- referência é formada por duas facetas, que Taylor denomina maneira e matéria (1994, p. 111). No primeiro caso, a autenticidade refere-se à maneira de ser capaz de levar a cabo qualquer fim ou forma de vida escolhida. Mas o conteúdo dessa forma de vida pode encontrar significado em diferentes âmbitos - pode-se expressar ou encontrar realização na religião, na política, na arte, na defesa do meio ambiente, entre outros.

O problema ocorre quando as duas esferas se confundem, quando não apenas a vida passa a ser guiada por orientações pessoais, como o conteúdo da forma de vida escolhida tem como referência apenas a si mesmo. O individualismo radical é fruto da "confusão" entre as duas classes de auto-referência, 'maneira' e 'matéria', dando a ilusão de que a auto-referência da matéria é tão inevitável quanto a da maneira, levando a um atomismo e a um antropocentrismo exacerbado. É necessário ter como conteúdo das ações algo que está além de si mesmo.

O autor não propõe que o conteúdo das ações deva ser determinado por algo externo, a condução da vida deve ser orientada por escolhas internas. Tais escolhas é que não podem ter como única referência o "próprio umbigo". O ideal de autenticidade impõe que se deve ser fiel a si mesmo, recuperar o próprio sentiment de l'existence (1994, p. 120), mas na condição de ser social formado a partir de uma relação dialógica. Esse sentimento só será alcançado em sua plenitude se acompanhado do reconhecimento de que ele o coloca em relação com um todo mais amplo.

O reconhecimento da diferença implica na reivindicação da autenticidade que, juntamente com a dignidade, constituem o "excepcionalismo moral ocidental” (SOUZA, 2003, p. 67) que perpassa todo indivíduo ou sociedade moderna. Os sujeitos na modernidade são marcados pela tensão entre a defesa de uma dignidade universal e a busca do reconhecimento de suas particularidades. A não realização de uma dessas esferas priva o ser humano de uma necessidade humana vital: o reconhecimento. No campo mais aplicado, é difícil exigir

expressivistas, a linguagem exerce basicamente três funções: (1) expressiva: é a forma que os humanos articulam sentidos de uma maneira complexa e densa; (2) a linguagem serve para expor algo entre os interlocutores (notadamente no espaço público) e; (3) pela linguagem, nossas inquietudes mais importantes podem formularse, articular-se para impactar-nos, adotando uma forma constitutiva. (1994, pg. 22) 
${ }^{15}$ De acordo com Taylor, o ideal de autenticidade é fruto do período romântico, que se mostrava crítico em relação à racionalidade não comprometida e ao atomismo que não reconhecia os laços da comunidade. A noção de autenticidade se desenvolveu a partir do momento em que estar em contato com os próprios sentimentos morais permite que se atue corretamente, um contato que deve ter um significado moral independente. Ocorre quando é possível defender uma identidade individualizada, formada a partir de um sentido moral, dado agora por uma voz interior que permite ao sujeito diferenciar o bom do mau, sem estar atrelado a dogmas religiosos. Esse giro subjetivo característico da cultura moderna faz com que a "salvação moral” dependa da recuperação de um autêntico contato moral consigo mesmo. O ideal de autenticidade, aliado ao princípio da originalidade, determina que se tem um modo original de ser e que o modelo de vida a ser perseguido não deve ter como referência algo externo, mas deve ser encontrado dentro de si: "ser fiel a mim mesmo significa ser fiel a minha própria originalidade, que é algo que só eu posso articular e descobrir" (TAYLOR, 1993, pg. 51). 
reconhecimento sem integração, o que justifica a necessidade de um enfoque global por parte das políticas migratórias, de modo que estas também apreendam a integração como passo imprescindível para que haja reconhecimento de identidade e de direitos, como propuseram, por exemplo, as Nações Unidas a partir do encontro sobre Migrações e Desenvolvimento, realizado em 2006. ${ }^{16}$ É esse o desafio a ser explorado no item seguinte.

\section{Reconhecimento e Direito}

Da relação necessária entre identidade e reconhecimento decorre a vinculação entre Teoria do Reconhecimento e Direito. Essa relação foi sustentada por Hegel a partir de alguns pressupostos fundamentais acerca da subjetividade, tais como: ${ }^{17}$

1. A subjetividade é criada por meio da luta entre pessoas pelo reconhecimento recíproco de sua identidade;

2. A vida ética é o viver bem praticado e experimentado por cada cidadão;

3. O movimento do espírito na história: do direito à moralidade, à vida ética no domínio dos princípios morais, ao Estado nas instituições está repleto de contradições e conflitos que são gradativamente absorvidos na marcha do espírito em direção à consciência-de-si; e

4. O eu constitui-se reflexivamente na sua dependência radical de outros.

Partindo da premissa de que a conservação intersubjetiva da identidade do Eu é a experiência originária da dialética, Hegel propõe um modelo a partir do qual a estrutura que torna compreensíveis a natureza e a história em sua essencial multiplicidade é, ao mesmo tempo, a estrutura através da qual o eu deve criar e manter a própria identidade. Isto permite que o espírito subjetivo - o Eu - possa ser pensado de modo universalista como vontade livre e, ao mesmo tempo, ser identificado com a particularidade de um determinado espírito do povo e de um Estado particular.

Em Hegel, a individuação depende da subjetivação crescente do espírito. Para George Herbert Mead, ela resulta da internalização das instâncias controladoras do comportamento, que imigram de fora para dentro (HABERMAS, 1990, p. 185). A individualização ocorre, portanto, pelo processo de integração e generalização das expectativas que fazem as pessoas em relação às outras. Essa integração e generalização ocorrem de maneira abstrata e permitem gerar ações autônomas, resultantes das interpretações e relações feitas entre as diversas 
${ }^{16}$ Neste sentido, é importante que se destaque o debate sobre a cidadania e, particularmente, sobre sua negação, àqueles que vêm de fora. No entanto, por limites impostos pela própria proposta do presente artigo, não entraremos nessa discussão. Para um aprofundamento destas questões, ver Santos (1979), Mouffe (1992), Soysal (1994), Fernandes (1995), Vieira (1997), Cohen (1999), Avritzer (2002) e Batista (2009).

${ }^{17}$ Seguindo a análise empreendida por Douzinas (2009). 
expectativas, algumas até contraditórias, dando ensejo a um movimento interior de autocomando do comportamento, que é único.

Mead entende a individuação como um processo linguisticamente mediado da socialização e, ao mesmo tempo, da constituição de uma história de vida consciente de si mesma. ${ }^{18}$ Esta afirmação determina que a individualidade seja formada pelo reconhecimento intersubjetivo e pelo autoentendimento mediado também de maneira intersubjetiva, o que torna a linguagem essencial à formação de qualquer sujeito. A partir do momento em que se configura a importância que as relações intersubjetivas tem na conformação das personalidades, não há como falar de direitos humanos sem referência ao reconhecimento.

Taylor defende a ideia de que o reconhecimento é uma necessidade humana vital, porque o falso reconhecimento ou a falta de reconhecimento podem constituir uma forma de opressão que aprisiona alguém em uma interpretação de si mesmo falsa, deformada e reduzida. Recorrendo a estudo desenvolvido por Frantz Fanon, Taylor (2001, p. 96) demonstra que a principal estratégia dos colonizadores é a imposição de uma imagem depreciativa aos povos colonizados. Desta maneira, a libertação destes povos estaria condicionada a um processo lento e difícil de modificação desta autoimagem distorcida.

Uma sociedade que se pretenda efetivamente democrática deve ter como uma de suas preocupações centrais o desenvolvimento do reconhecimento igualitário, porque a sua ausência pode constituir uma das formas mais graves de opressão, ao aprisionar uma pessoa ou um grupo de pessoas em uma modalidade distorcida e redutora de ser, o que pode condicioná-lo(s) a uma situação de submissão e violência dificilmente reversível.

A política da dignidade universal prega uma forma de não-discriminação cega aos modos em que se diferenciam os cidadãos ao basear-se na ideia de que todos os seres humanos são iguais. Partindo de uma premissa liberal procedimental - ou liberalismo $1^{19}$ - em que o Estado deve manter uma posição de neutralidade em relação às perspectivas culturais e demais metas coletivas, essa política inaugura um modelo de aplicação uniforme das regras que definem os direitos fundamentais, desconsiderando as metas coletivas. Nesse sentido, os confrontos culturais são entendidos como espécies de conflito entre concepções individuais e que, por isso, não devem ser objeto de preocupação das instituições públicas.

\footnotetext{
${ }^{18}$ Esse entendimento demonstra a influência dos pensadores Humboldt e Kierkgaard na psicologia social de Mead. (HABERMAS, 1990, pg. 186)

${ }^{19}$ Os dois tipos de liberalismo que Taylor descreveu no texto Política de Reconhecimento foram redefinidos vol.09, nº. 02, Rio de Janeiro, 2016. pp. 
por Michael Walzer como Liberalismo 1 e Liberalismo 2. De acordo com Walzer, o liberalismo 1 seria aquele comprometido da maneira mais vigorosa possível com os direitos individuais e com um Estado rigorosamente neutro. Já o liberalismo 2, seria aquele pautado em um Estado comprometido com a sobrevivência e o florescimento de uma nação, cultura ou religião em particular, ou de um limitado conjunto de nações, culturas e religiões, na medida em que os direitos básicos dos cidadãos que têm diferentes compromissos estejam protegidos. O liberalismo 2 seria, portanto, mais tolerante e indeterminado, na medida em que não aceita opções singulares e definitivas, mas adapta sua política às suas circunstâncias. Diversamente da postura defendida por Taylor, Walzer conclui sua análise optando pelo Liberalismo de primeiro tipo. (TAYLOR, 2001, pgs. 139-145). 
A política da diferença, por sua vez, redefine a não discriminação exigindo que as particularidades constituam a base de um tratamento diferencial. $\mathrm{O}$ caminho vislumbrado por Taylor para atingir uma forma de reconhecimento pleno só poderá ocorrer via política da diferença, porque para ele "uma sociedade supostamente justa e cega às diferenças não só é inumana - na medida em que suprime as identidades - senão também, de maneira sutil e consciente, resulta discriminatória" (2001, p. 67).

Esta perspectiva se demonstra realizável em uma sociedade pautada em uma postura liberal substantiva, ${ }^{20}$ ou seja, um Estado comprometido com a sobrevivência da diversidade cultural, atuando de forma positiva para sua preservação. Sendo ainda uma vertente do liberalismo não pode servir de base para um campo de reunião para todas as culturas, mas apenas a expressão política de certo gênero de culturas, estabelecendo limites a determinadas manifestações culturais que se apresentem totalmente incompativeis com os princípios políticos fundamentais de cada comunidade (TAYLOR, 2001, p. 94). ${ }^{21}$

As reflexões do autor canadense são centrais no debate sobre reconhecimento, mas a teoria que melhor determina a relação entre reconhecimento e direito é a desenvolvida por Axel Honneth. ${ }^{22}$

\section{Axel Honneth e as três esferas do reconhecimento}

Com forte inspiração nos trabalhos de Hegel e Mead, Honneth vai determinar que uma relação de reconhecimento não distorcida deve conter todos os pressupostos subjetivos que precisam os sujeitos para se sentirem protegidos nas condições de sua autorealização ${ }^{23}$ autorealização. Honneth (2003) traça uma tipologia fenomenológica pautada em três padrões de reconhecimento: amor, direito e solidariedade.

Honneth entende o amor como todas aquelas relações primárias baseadas em ligações fortes entre poucas pessoas, tenham elas a forma das relações entre pais e filhos, relações de amizade ou relações eróticas entre dois parceiros. Nestes casos, dois sujeitos sentem-se unidos pela relação de dependência do respectivo outro. A confiança de que a pessoa amada preserva sua afeição mesmo que sua atenção não esteja sendo direcionada a ela,

\footnotetext{
${ }^{20}$ Liberalismo 2.

${ }^{21}$ Para determinar esses limites não há alternativa senão o recurso à idéia de razoabilidade.

${ }^{22}$ Além de Axel Honneth, Nancy Fraser representa referência obrigatória no debate do reconhecimento aliado à ideia de justiça. Diferentemente do autor, Fraser propõe um modelo de justiça que alia as ideias de redistribuição e reconhecimento através do conceito de paridade de participação. Além de separar as esferas da redistribuição da de reconhecimento, outro ponto de desacordo entre Fraser e Honneth está em que o vol.09, nº. 02, Rio de Janeiro, 2016. pp. 
representante da Escola de Frankfurt constrói sua teoria a partir das influências teóricas de Hegel, Mead e Winnicott sobre identidade e subjetividade, enquanto que a autora substitui a ideia de identidade pela de status. O enfrentamento das principais diferenças entre as duas propostas fugiria aos estreitos limites desse trabalho e já foram devidamente exploradas pelos próprios pensadores em obra conjunta (2003).

${ }^{23}$ Nesse sentido, torna-se necessário desvincular-se de uma concepção da moral de matriz Kantiana, porque a moral entendida do ponto de vista do respeito universal leva a uma compreensão liberal dos bens que formam a concepção de vida boa. Tampouco se deve buscar respostas nas teorias éticas comunitaristas que procuram formar o ethos de uma comunidade a partir de tradições concretas. A abordagem da teoria do reconhecimento deve estar no meio do caminho entre essas duas concepções, partilhando com a primeira o interesse por normas universais que garantam condições de possibilidade mínimas para um desenvolvimento satisfatório da vida e com a segunda as orientações pelo fim da auto-realização humana. 
dá ao outro uma certeza amadurecida de que as suas carências vão encontrar permanente satisfação por parte da primeira. A autoconfiança, ou capacidade de estar só, nasce da autorelação a que um sujeito pode chegar quando se sabe amado por uma pessoa vivenciada como independente, pela qual ele também sente amor ou afeição. A forma de reconhecimento do amor, portanto, é pautada na tensão entre o poder-estar-só e o estar-fundido. Ao contrário, as formas de desrespeito que atingem essa esfera do reconhecimento são caracterizadas pelo autor como maus-tratos, porque esse tipo de desrespeito é experimentado pelo ataque à integridade física.

O segundo padrão, o direito, só pôde refletir uma forma de reconhecimento com a modernidade, quando o sistema jurídico passou a ser entendido como a expressão de interesses universalizáveis e a obediência às normas jurídicas passou a estar condicionada ao seu assentimento por seres livres e iguais. Ao obedecer à mesma lei, os sujeitos de direito se reconhecem reciprocamente como pessoas capazes de decidir com autonomia individual sobre normas morais. Se todos os seres humanos são racionais, são capazes de decidir autonomamente sobre as normas que desejam seguir, e por essas razões, são todos dignos de respeito. $\mathrm{O}$ direito permite uma forma de reconhecimento que independe da estima por suas realizações e características particulares, as propriedades que identificam a pessoa servem de fundamento a essa forma de respeito.

As lutas por reconhecimento nessa esfera têm por objetivo conceder àqueles que estão excluídos dessa relação as condições necessárias para a participação igual no acordo racional. A criança adquire a autoconfiança a partir da experiência contínua da dedicação materna. $O$ adulto, por sua vez, só vai poder conceber sua ação como manifestação de sua própria autonomia, respeitada por todos, a partir da experiência do reconhecimento jurídico.

É o caráter público que os direitos possuem [...] o que lhes confere a força de possibilitar a constituição do autorespeito; pois com a atividade facultativa de reclamar direitos, é dado ao indivíduo um meio de expressão simbólica, cuja efetividade social pode demonstrar-lhe reiteradamente que ele encontra reconhecimento universal como pessoa moralmente imputável (HONNETH, 2003, p. 197).

O terceiro padrão de reconhecimento é chamado de solidariedade. Para que um sujeito alcance sua autorealização, além da autoconfiança e do autorespeito, é preciso que ele tenha ainda autoestima. Aliado à experiência da dedicação afetiva e do reconhecimento jurídico, os sujeitos humanos dependem de uma estima social que lhes permita referir-se positivamente às suas propriedades e capacidades concretas.

Nesse caso, os seres humanos são reconhecidos quando suas propriedades singulares vol.09, nº. 02, Rio de Janeiro, 2016. pp. 
contribuem para o desenvolvimento daquela sociedade. A estima social depende do contexto de vida social compartilhado pelos membros de uma comunidade de valores. É a autocompreensão cultural de uma sociedade que predetermina os critérios que irão definir se uma pessoa pode ou não ser estimada.

Honneth relaciona essa forma de reconhecimento à ideia de solidariedade, para designar uma espécie de relação interativa na qual os sujeitos têm interesse recíproco pelos distintos modos de vida, pelo fato de se 
estimarem entre si de maneira simétrica. ${ }^{24}$ São relações solidárias porque elas "não despertam somente a tolerância para com a particularidade individual da outra pessoa, mas também o interesse afetivo por essa particularidade" (2003, p. 211).

Cada um desses padrões estaria responsável pela conformação de uma parcela da autorealização. Do amor é construída a autoconfiança; do direito, o autorrespeito; e com a solidariedade, a autoestima.

A autoconfiança é atacada quando é retirada violentamente a possibilidade da livre disposição sobre o próprio corpo. O sujeito que sofre este tipo de desrespeito perde a confiança em si e no mundo e acaba sendo acometido por uma espécie de vergonha social. A segurança afetiva propiciada pela experiência intersubjetiva do amor, constitui o pressuposto psíquico do desenvolvimento de todas as outras atitudes de autorrespeito, na medida em que a autoconfiança individual é a base indispensável para a participação autônoma na vida pública.

$\mathrm{O}$ autorrespeito constitui a possibilidade do indivíduo se referir positivamente em relação a si mesmo e é gerado pela capacidade de participar autonomamente na formação discursiva da vontade. A sua ausência também gera uma espécie de vergonha social que paralisa ofendidos. Só o protesto ativo e a resistência a uma situação de subprivilégio jurídico pode recuperar o autorrespeito dos excluídos. Para o indivíduo, a denegação de pretensões jurídicas socialmente vigentes significa ser lesado na expectativa de ser reconhecido como sujeito capaz de formar juízo moral.

O desrespeito à forma de reconhecimento solidariedade se dá quando alguns modos de vida ou crenças são considerados de menor valor. Nesse caso, retira-se do sujeito a possibilidade de atribuir um valor social às suas próprias capacidades. A forma de vida por ele escolhida é depreciada a tal ponto que deixa de ter um significado positivo no interior daquela coletividade. Internamente, essa forma de desrespeito gera uma perda de autoestima pessoal, tendo em vista que o sujeito não consegue entender a si próprio como um ser estimado por suas capacidades e propriedades características.

\section{Reconhecimento e as migrações}

Em relação à esfera do amor pouco pode ser dito em relação ao imigrante africano no Brasil, na medida em que não são conhecidos dados sobre o processo de constituição da autoconfiança desses indivíduos. Quanto às duas últimas esferas trabalhadas, ao contrário, é possivel avaliar se sofrem de falta ou falso reconhecimento na sociedade brasileira. 
A regulamentação da imigração tem um objetivo nítido, embora não revelado: impor a definição de imigrante que precisa ser constituída em função das necessidades de cada momento, de cada circunstância, mudando constantemente ao sabor da conjuntura e das oscilações de população.

${ }^{24}$ Simétrico significa que todo sujeito recebe a chance, sem graduações coletivas, de experienciar a si mesmo, em suas próprias realizações e capacidades, como valioso para a sociedade. 
Os imigrantes se habituaram a reivindicar, de forma muitas vezes extremada, seus direitos em plano integral, não apenas os direitos trabalhistas, parciais e, frequentemente, incompletos. Esse fato levou a uma inversão da contabilidade: imigração e imigrantes só são tolerados, na prática, quando no balanço entre custos e lucros, vantagens e desvantagens, se apresenta um saldo positivo, ou seja: a imigração só deve apresentar "vantagens”, especialmente as econômicas, sendo que as "desvantagens" (custo social e cultural) devem ser evitadas a qualquer preço.

Do ponto de vista jurídico, o trabalho é o salvo conduto do imigrante voluntário, estando sua estadia condicionada a ele, ou seja, juridicamente falando, sem trabalho não há imigrante. Porém, não se trata de qualquer trabalho, mas daquele em cujo mercado há lugar para o imigrante. Imigrante desempregado não pode permanecer na condição de imigrante. A possibilidade de um estrangeiro se estabelecer em solo alheio só ocorre em sua relação estreita com o mercado de trabalho. ${ }^{25}$

O caso daquelas pessoas que entram no país através de algum tipo de intercâmbio para estudos é um pouco diferente, na medida em que ao ter concedido o visto de estudante (temporário IV, conforme a legislação brasileira em vigor) fica-lhe vedada a possibilidade de exercer atividade remunerada, sob pena de multa, notificação ou mesmo deportação. Em princípio o visto tem validade de um ano, podendo ser prorrogado por igual período por sucessivas vezes, desde que seguidas as normas para renovação - o que pode prolongar de forma indeterminada esta experiência, sendo o limite de renovações estabelecido pelo curso no qual o estudante está matriculado.

A condição de imigrante ${ }^{26}$ é uma condição social, enquanto a definição de estrangeiro é um termo jurídico (SAYAD, 1998, p. 243). Sayad (1998) argumenta acerca do "paradoxo da imigração", que traz em si três ilusões: a da provisoriedade; a da legitimação da presença por meio do trabalho; e a da neutralidade política. Essas ilusões alimentadas pelos imigrantes fazem com que eles vivam como "estrangeiros", sustentados por ficções como a do retorno, que muitas vezes se torna impossível; e a da naturalização, que muitas vezes é embaraçada por questões políticas, sociais e culturais.

A valorização de suas formas de vida seria responsável pela última esfera de reconhecimento. Quando aportam em solo brasileiro, os imigrantes trazem consigo experiências, costumes e valores que, se não forem identificados positivamente pela sociedade brasileira, os submeterá a um falso reconhecimento ou à sua ausência completa. Nesse aspecto, o racismo 
$\overline{\text { naturalizado na sociedade brasileira, submete tais pessoas a uma imagem distorcida e degradante }}$ em relação a si mesmo.

${ }^{25}$ Impende esclarecer que o conceito do Direito acerca do imigrante está estabelecido na norma jurídica (legislação, costume, jurisprudência), sendo distinto do conceito sociológico e do conceito político. Para mais elementos sobre esse debate, conferir, SAYAD (1998: 51) e BATISTA (2009: 69).

${ }^{26}$ Os estudantes africanos não são, portanto, imigrantes, mas estrangeiros com autorização "temporária de permanência”, de uma forma mais precária ainda que o imigrante com visto de trabalho. 
Os africanos, ao entrar no país, sofrem uma desconfiança especial das autoridades da imigração, que a todos enquadram no estereótipo do traficante internacional de drogas. Esse tratamento é reproduzido nas abordagens policiais e nas outras formas de manifestação do preconceito racial no Brasil, que depreciam a herança cultural e histórica negra não apenas nos seus valores intrínsecos, como na sua importância para a formação social brasileira (VIDA, 2001).

Assim, há uma constante dualidade na situação do imigrante, que se manifesta numa "lógica da exclusão", segundo a qual, a fim de tentar preservar sua identidade, o imigrante “exclui a si mesmo antes de ser excluído e também para não ser excluído” (SAYAD, 1998, p. 269).

A tese de Honneth (2003) é a de que o elo psíquico que conduz do sofrimento à ação pode ser desempenhado pelas reações emocionais negativas como a vergonha, a ira, a vexação, ou o desprezo. Nesse sentido, a tensão afetiva gerada pelo sofrimento humano força o indivíduo a se insurgir contra a realidade que o oprime. $O$ indivíduo não pode se comportar de modo emocionalmente neutro em relação às ofensas sociais, aos maus-tratos físicos ou à privação e exclusão de direitos. As reações emocionais negativas, vivenciadas pelo desrespeito de pretensões de reconhecimento, contém em si a possibilidade de que a injustiça imposta ao sujeito se revele, em termos cognitivos, como combustível para a resistência política.

Pelo que se depreende da proposta de Honneth, a luta por reconhecimento dos imigrantes africanos no Brasil seria informada pelas seguintes demandas:

1. Pela garantia da possibilidade da livre disposição sobre o próprio corpo;

2. Pela concretização de pretensões jurídicas socialmente vigentes e possibilidade de participar na conformação do conteúdo de novas pretensões; e

3. Pela contestação de práticas sociais, políticas públicas e omissões que perpetuem ou instituam visões hierarquizantes e depreciativas do Outro.

\section{IMIGRAÇÃO COMO CONDIÇÃO SOCIAL: ESTUDANTES AFRICANOS E O RECONHECIMENTO}

A problematização do fenômeno migratório, da forma como vivenciado no mundo contemporâneo é posterior à descolonização africana e asiática, quando os antigos colonizados passaram a migrar para os países ex-colonizadores na Europa. O direito internacional só se ocupara, até então, da discussão acerca dos limites da soberania, ficando a polêmica sobre os 
Quaestio Iuris

$\overline{\text { direitos dos estrangeiros e imigrantes restrita à seara da filosofia, que se ocupava em construir um }}$ "direito cosmopolita", como se percebe nos textos de Francisco de la Vitoria e, posteriormente, de Kant, em seu livro sobre a paz perpétua. $O$ pensamento europeu contemporâneo retomou vol. 09, nº. 02, Rio de Janeiro, 2016. pp. $757-787$ 
essa discussão recentemente, potencializando o discurso kantiano ao atribuir a organizações internacionais como a ONU e a União Européia o papel de organismos preferenciais para a defesa da paz e dos direitos humanos. ${ }^{27}$

O debate jurídico se limitou a tentar conciliar a antinomia entre o individual - liberdade de ir e vir - e o coletivo - representado pelo interesse público consagrado na soberania do Estado (CAVARZERE, 2001). No início do século XX, muitos países reconheceram a preponderância da liberdade individual sobre o interesse coletivo, sendo que alguns, dentre eles o Brasil, chegaram a abolir o uso de passaporte. Depois da Primeira Grande Guerra, no entanto, novamente começou a ter mais peso a questão da soberania nacional, baseados na qual os Estados podem regulamentar a admissão e expulsão de estrangeiros, de acordo com sua conveniência. Para evitar o "conflito de soberania" entre os Estados, o tema do direito internacional passou a ser soberania interna vs. comunidade das nações (CAVARZERE, 2001). Nesse diapasão, as normas sobre admissão de estrangeiros passaram a ser adotadas, mesmo que com limites, a fim de não se ofender a soberania de outro Estado soberano.

O processo migratório não pode ser reduzido à simples transferência de uma comunidade política para outra, mas de todo um processo de inclusão e aceitação em outro território e no seio de outra comunidade política, nem sempre receptiva ou disposta a aceitar novos membros em suas atividades econômicas, políticas, sociais, culturais, etc. Assim, embora haja nos textos internacionais e nas constituições contemporâneas a promessa de igualdade jurídica e de democracia republicana, a ausência de uma ligação formal da pessoa (como a aquisição da nacionalidade ou o estatuto de refugiado, por exemplo) ao território no qual escolheu viver, ou foi forçado a se instalar, pode lhe negar qualquer sentido de cidadania e, portanto, capacidade de participar de qualquer forma positiva da democracia no país de acolhida (PREUSS, 2008).

\section{As contradições da condição de imigrante}

Ao definir a tensão entre a transitoriedade e permanência que rondam o imigrante, Sayad (1998) alerta para o seguinte fato: de direito, a situação do imigrante é eminentemente provisória; por outro lado, o Estado sempre procura desmentir esse fato, insistindo na possibilidade de instalação dos imigrantes de forma duradoura, como imigrante! Para o autor, é como se a imigração precisasse, para se perpetuar, negar a si mesma, ignorando-se como provisória e não se confessando como definitiva. 
$\mathrm{Na}$ verdade, essa contradição fundamental é inerente ao fenômeno migratório. Os próprios imigrantes têm interesse nessa situação, pois ao adentrarem numa sociedade que não é a sua originariamente, lidam com a possibilidade de retornarem ao lugar a que pertencem. Suas comunidades de origem tampouco aceitam sua partida definitiva, lidando com sua ausência "temporária" sem aceitar que pode ser para sempre. E, finalmente, as

${ }^{27}$ Dentre os pensadores contemporâneos que discutem a questão do direito cosmopolita destacamos HABERMAS, BENHABIB, DE GREIFF E ZOLO. 
comunidades de destino, apesar de prepararem para o imigrante um estatuto que o mantém em caráter provisório, muitas vezes como se ele fosse apenas tolerado, negando-lhe a possibilidade de reconhecer sua situação como permanente, permite que o imigrante seja tratado, quando lhe interessa, como se o provisório pudesse durar indefinidamente.

A questão reside basicamente, no mundo contemporâneo, na expansão econômica, na necessidade de mão-de-obra permanente em grande quantidade, baseada, muitas vezes, na imigração. Empregadores, poder público, partidos políticos e sindicatos, por longo período entenderam que os instrumentos jurídicos internacionais e nacionais sobre imigração eram tranquilizadores, pois viam no imigrante a possibilidade de crescimento econômico e correção dos dados demográficos. Com isso, os imigrantes, ainda que relegados aos níveis inferiores da escala social, obtiveram por décadas um estatuto "permanente mas provisório", seja por sua utilidade econômica e social, no primeiro caso, seja por se estimar, no segundo caso, que trazem um "custo social" elevado ao impor sua presença à sociedade (SAYAD, 1998).

Diante desse quadro de contradições, pode-se analisar a questão migratória por meio de três principais pontos de vista. O viés social diz respeito às diversas ações de integração e adaptação do imigrante em seu novo país. O viés político abrange os acordos de mão-de-obra, as convenções bilaterais entre os países de emigração, que tratam das condições de entrada, de estadia, de trabalho, e que se definem conforme as diferentes relações de força existentes na política internacional (um acordo entre Brasil e Argentina, por exemplo, não terá as mesmas regras que aquele celebrado entre Brasil e Estados Unidos). O viés jurídico da questão migratória se relaciona com os direitos que devem ser reconhecidos ao imigrante, ao lugar em que ele vai trabalhar, residir, aos direitos de nacionalidade.

Dentro desse concerto, a "política de imigração" torna-se mais evidente em contextos de crise econômica, desempregos e dificuldades, pois lançam-se sobre ela as luzes, a fim de orientar a imigração no sentido dos interesses materiais e simbólicos que lhe são atribuídos. Os diversos discursos que são construídos em tempos de crise são discursos voltados para a imigração, atingem-na diretamente, como numa relação direta de causa- efeito, em que a imigração é pretexto para práticas e decisões administrativas (como maior rigor nas fiscalizações, concessão de vistos de trabalho e concessão de "auxílios para o retorno"); e para justificar o endurecimento de textos legislativos que tratem da entrada e estadia de imigrantes. O objetivo é lembrar aos imigrantes que são trabalhadores tolerados provisoriamente e retomar a definição "adequada" de imigrante. 
Nessa lógica, o que é um imigrante? Para Abdelmalek Sayad, na sua essência, o imigrante é uma "força de trabalho provisória, temporária, em trânsito", cuja condição é revogável a qualquer tempo (1998, p.54-55). É a partir dessas reflexões que deve ser abordado o histórico da regulamentação jurídica das migrações, no recorte cronológico do século XX, levando-se em consideração que essa regulação evoluiu ou retrocedeu ao sabor das 
transformações econômicas e das variações dos interesses dos países que dominaram o cenário internacional ao longo desse tempo. Deve-se, ainda, considerar a globalização, envolta no espírito capitalista, que molda e contextualiza o regime jurídico das migrações. Entretanto, ressalve-se que cabe ao direito, especialmente, conjugar os fatores econômicos com a prevalência dos direitos humanos sobre os interesses econômicos.

\section{Ser africano no Brasil}

A presença africana no Brasil é quase tão antiga quanto o próprio país, mesmo tendo sido os africanos parte essencial da formação da sociedade brasileira, os africanos que hoje chegam ao Brasil convivem com a dicotomia entre a lei e a prática. A simbólica abolição da escravatura no Brasil foi construída em cima de normas ${ }^{28}$ que não tiveram o objetivo real de promover liberdade e emancipação. Depois da proclamação da República em 1889, começou-se a incentivar a imigração europeia, com o objetivo de "embranquecer" a população e com isso garantir seu processo de modernização e urbanização, política esta mantida na era Vargas de forma explícita. ${ }^{29}$

Apesar de todo esse histórico de racismo, a sociedade brasileira assumiu por um tempo o slogan de "democracia racial", negando repetidamente os problemas existentes e praticando de forma reiterada atos de discriminação racial. Essa atitude se reflete na recepção aos imigrantes africanos na atualidade, comumente identificados com o subdesenvolvimento, catástrofes humanitárias, guerras tribais e epidemias, que compõem um mosaico estereotipado das pessoas oriundas do continente africano (VIDA, 2001).

Pensar a questão identitária a partir da situação de migrantes, independente de sua condição, é preciso levar em conta a ideia de uma situação ambivalente, de pertencimentos múltiplos e dos não-pertencimentos que a condição "em trânsito" os colocam. Esta situação, contudo, não deixa de carregar também diversas tensões e conflitos, tanto internos quanto externos ao indivíduo (MORAIS E SILVA, 2010). Nas palavras de Gusmão (2008, p.9): “o que esses estudantes vivem no processo de deslocamento cria uma visibilidade/invisibilidade, denota uma presença e uma não presença resultantes da condição diaspórica que os coloca 'fora de lugar'."

Vida (2001), ao investigar a cobertura da imprensa nos anos 1990 a respeito da imigração africana para o Brasil, percebeu a identificação do imigrante africano com os refugiados ou com a delinquência. Este anti- africanismo produz desconfiança em relação à população africana 
$\overline{\text { imigrante que é marginalizada na sociedade, é alvo permanente da desconfiança e abuso policial. }}$

Mesmo os empresários africanos radicados no Brasil, ou os que

\footnotetext{
${ }^{28}$ Durante o século XIX diversas leis foram promulgadas acerca da escravidão: Lei Diogo de Feijó, contra o tráfico de escravos,1831; Lei Eusébio de Queirós, que emancipava africanos ilegalmente traficados para o Brasil, 1853; Lei do Ventre Livre, que declarava livres os filhos de escravos nascidos no Brasil, 1871; Lei dos Sexagenários, que libertava os maiores de sessenta anos, 1885; Lei Áurea, que abolia a escravidão, 1888.

${ }^{29}$ No decreto de 18 de setembro de 1943, Getúlio Vargas se compromete com a política de eugenização: "Atender-se-á na admissão dos imigrantes a necessidade de preservar e desenvolver, na composição étnica da população, as características mais convenientes da sua ascendência européia".
} 
exercem suas profissões como professores visitantes, todos portadores de vistos de trabalho, são vítimas de preconceito e discriminação, como se 'ser africano' e 'trabalhador ou empresário' fossem conceitos inconciliáveis. Não raro são relatados casos de abordagens abusivas ou jocosas a esses profissionais por parte de funcionários públicos, funcionários de bancos e até mesmo clientes (VIDA, 2001).

Apontaremos a seguir alguns aspectos que caracterizam essa realidade "em trânsito", em particular dos africanos que vêm ao Brasil com o objetivo de avançar em seus estudos superiores, ou que vêm ao país pedir a chance de dar continuidade à vida, longe de conflitos. De maneira geral, esta realidade gera dois esforços internos aos indivíduos que migram e que encontram nos outros que estão na mesma situação uma força para se sustentar: por um lado, percebe-se a tentativa destes indivíduos que estão "na terra do outro" (GOMES, 2002 apud GUSMÃO, 2011) de se inserirem na comunidade local; por outro lado, também é notável uma percepção de si mesmos (enquanto negros, africanos, angolanos, guineenses, cabo-verdianos, entre tantas outras identificações), a partir do contraste com "o outro", e um esforço para assumir esta identidade percebida na mesma "terra do outro" (MUNGOI, 2004). Durante todo este tempo existe uma tensão entre manter suas tradições e se abrir para novas experiências.

\section{Estudar no Brasil: a experiência africana}

Os estudantes africanos ocupam cerca de $70 \%$ das vagas dos programas PEC-G e PECPG do governo brasileiro. ${ }^{30} \mathrm{~A}$ afluência de nacionais desses países se deve à necessidade de ter um certificado de proficiência em língua portuguesa (o CELPE-Bras), o que facilita a seleção de africanos lusófonos. O êxodo de estudantes africanos se explica pela precariedade do sistema educacional de seus países de origem.

Vários autores (GUSMÃO, 2008 a, b e 2011; SILVA, 2010; SOUZA, 2010; SUBUHANA, 2009)

separam três dimensões contidas dentro do trajeto de travessia do Atlântico para estudar no Brasil: busca-se uma qualificação pessoal, de maneira a ter mais chances de ascensão e mobilidade social quando do retorno; mas ao mesmo tempo, a decisão também faz parte de um projeto familiar, tendo em vista que geralmente envolve o esforço de muitos que ficaram na África; e também um projeto maior nacional desenvolvimentista de seus países de origem.

Este percurso de migração, nas palavras de Gusmão (2008b) "é tudo, menos individual”, o que implica num vínculo de responsabilidade por parte daquele que emigra, no sentido de 
$\overline{\text { gerar um compromisso tácito de retorno dos investimentos realizados neles. De acordo com }}$ Subuhana (2009), para além do compromisso

\footnotetext{
${ }^{30}$ De acordo com os dados publicados, considerando tanto o PEC-G quanto o PEC-PG, até 2013, os estudantes africanos representavam cerca $65 \%$ do total de estudantes recebidos pelo Brasil. Quando considerados apenas os estudantes do PEC-G, até 2015, os africanos representavam mais de 77\% do total de imigrantes acolhidos pelo programa. Fonte: http://www.dce.mre.gov.br/PEC/apresentacao.php, consultado em 17/12/2015.
} 
firmado pelo convênio, muitos dos estudantes que vieram via PEC-G ou PEC-PG, demonstram uma vontade de retornarem às suas terras natais de modo a contribuir para seu desenvolvimento com os conhecimentos adquiridos aqui.

Os estudantes africanos são alvo constante de preconceitos, o que, aliado à falta de recursos e às poucas iniciativas oficiais de concessão de bolsas e incentivos, interfere nos estudos e na qualificação desse contingente (KALY, 2001). Um ponto consensual é a percepção do preconceito e da prática de discriminação dos brasileiros em relação às pessoas de pele negra sejam elas brasileiras ou africanas. Como destaca Subuhana (2009, p.121), "vale notar que, mesmo entre os negros, há aqueles que afirmam ter mais facilidade de detectar que estão sendo discriminados em relação aos outros. Talvez sejam vítimas de discriminação sofisticada”. Outros autores também chamam atenção para a existência de um racismo sutil ou "camuflado" (GUSMÃO, 2008a) em paralelo a uma discriminação direta.

Muitos são os relatos sobre discriminação em situações cotidianas, como em ônibus, bancos, supermercados (MORAIS e SILVA, 2010) ou mesmo em sala de aula, como apontado por Gusmão (2008b). Segundo a autora, esta é uma situação nova para os africanos que aqui chegam, já que o racismo ou não é percebido na África ou não é praticado da mesma forma que no Brasil. Assim, os estudantes demoram a compreender e se adaptar a esta situação (SOUZA, 2010).

Se o preconceito relacionado à cor da pele é reconhecido cotidianamente pelos estudantes africanos, a reação da sociedade em relação à situação de imigrante é percebida por eles de diferentes maneiras: alguns percebem como indiferente a condição de imigrante nesta recepção, o preconceito é direcionado essencialmente pela cor da pele; outros percebem no fato de ser imigrante um fator "amenizador" da discriminação, pressupondo que a condição de imigrante é carregada de uma conotação positiva entre os brasileiros - o que normalmente acontece em locais comerciais, associando o imigrante a consumidor (MUNGOI, 2004; SILVA, 2010); e outros ainda perceberem uma rejeição pelo fato de serem imigrante, muito ligada à ideia de que os imigrante vêm para o país para tomar o lugar dos brasileiros, por exemplo no mercado de trabalho, ou para se aproveitar dos "benefícios"

- médicos, sociais, entre outros (GUSMÃO, 2008a). De todo modo, há a percepção por alguns da diferenciação existente entre ser negro brasileiro e ser negro estrangeiro (GUSMÃO, 2008a; SILVA, 2010). Em entrevista a Gusmão, Pedro destaca:

[...]estudantes africanos são, por um lado, aceitos pela população por serem considerados intelectuais universitários, munidos de uma condição financeira vol.09, nº. 02, Rio de Janeiro, 2016. pp. 
estável e estrangeiros (os estrangeiros são geralmente bem vistos); e, por outro lado, são expostos a toda discriminação racial e social, quando confundidos com afro-brasileiros. (GUSMÃO, 2011, p.194)

Os estudantes são inseridos bruscamente na realidade das instituições de ensino superior (IES) públicas brasileiras - um ambiente reconhecido como de segregação, de elite e de hierarquia de poder - de maneira 
marginalizada, devido à estigmatização e inferiorização do negro pelos estudantes brasileiros (GUSMÃO, 2008b; SOUZA 2010; SILVA 2010).

Passaremos agora a uma análise geral dos relatos de estudantes africanos que vieram fazer intercâmbio no Brasil, no intuito de destacar as experiências e os sentimentos destes ao longo da vivência.

\section{O intercâmbio de estudantes africanos e as esferas do reconhecimento}

Como os programas de intercâmbio são delineados internamente por cada universidade, a maior parte das vagas de intercâmbio acaba sendo dos estudantes de países desenvolvidos, que podem pagar as próprias despesas. O africano que vem ao Brasil estudar, beneficiado por convênios internacionais, sofre problemas parecidos com aqueles que o brasileiro negro e pobre no país, diferente do que ocorre com os intercambistas oriundos de países ricos, como europeus e norte-americanos, via de regra suportados por suas famílias e/ou países de origem. Reforça-se aqui a ideia de uma "superioridade civilizatória do Ocidente", em detrimento das civilizações africanas, aliada a uma enorme ignorância, no Brasil, em relação à África, o que desencadeia o desrespeito à forma de reconhecimento solidariedade.

Esse sentimento detona uma crise de autoestima (KALY, 2001), pois os estudantes africanos lidam diariamente com um status de identidade inferiorizante que lhes é atribuído pela população. Frequentemente, essa baixa estima se traduz na dificuldade de interação do estudante, devido à sua insatisfação até mesmo com relação aos diplomatas africanos no Brasil, pouco dispostos, muitas vezes, a intervir junto às autoridades brasileiras (VIDA, 2001).

Mungoi (2004) caracteriza logo o primeiro momento destes africanos no como um momento de autêntico "abandono” e "aventuras” -, há uma forte sensação de desamparo comum a muitos. Esta sensação pode ser percebida pelos relatos de suas chegadas, considerando desde o momento em que desembarca no aeroporto brasileiro, até o momento da instalação em uma moradia. Em primeiro lugar, chegam ao Brasil sozinhos e sem nenhuma referência para procurar - reclamam que não há ajuda de órgãos oficiais e nem da universidade que os acolhe.

Além disso, existem as dificuldades decorrentes das exigências feitas pelo setor imobiliário para se conseguir uma moradia, coisa que poucos conseguem cumprir, tendo em vista que os vistos de estudantes são temporários da categoria IV, ou seja, é proibido que eles exerçam qualquer tipo de atividade remunerada - o que também é apontado como "dificultador" da inserção do estudante na sociedade local (MUNGOI, 2004; GUSMÃO, 
Outros pontos estão presentes na grande maioria dos relatos sobre as experiências dos estudantes de intercâmbio de origem africana (GUSMÃO, 2008a e b; SILVA, 2010; MUNGOI, 2004) Um dos que mais 
chamam atenção é a falta de informações sobre a África e o desconhecimento sobre suas diversas realidades, muitas vezes pintadas em uma visão caricata quase fantasiosa. Algumas falas comuns de brasileiros ao interrogarem africanos, apresentadas no trabalho de Gusmão (2008a, p.13), caracterizam bem a situação:

Você vem da África? Mas lá falam português? "; "Lá vocês têm carro, luz elétrica? "; "Como você chegou aqui? De navio? ". Porque muitos assim, muitos amigos meus pensam assim: "puxa... lá em Angola ceis vivem em tribos, não sei o quê tal e tal". A gente fala não, a gente fala não, nós temos o nosso dia a dia. É vivenciamos como aqui, né? Lá existe também prédios, lá também dançamos, nos lá também bebemos. A vida lá é praticamente igual aqui, mas o brasileiro tem uma outra visão de como é a África. É essa a imagem que é passada, essa é a imagem que é passada, né? O pessoal nem tem uma outra imagem que caracterize realmente o mundo atual, digamos.

Outra dificuldade enfrentada é a da língua portuguesa e seus sotaques. Alguns estudantes africanos vêm estudar no Brasil de países anglófonos e francófonos. Segundo Mungoi (2004), para estes um dos períodos mais problemáticos da presença no Brasil é o de aprendizado da língua, havendo casos de desistência e abandono do país por causa dessas dificuldades. Entretanto, mesmo os estudantes vindos dos PALOP sofrem para se adaptar ao sotaque brasileiro. ${ }^{31}$ Esta é apontada como uma das grandes dificuldades de inserção dos estudantes na sociedade: os estudantes relatam intolerância por parte de seus colegas e mesmo de professores com suas "deficiências" linguísticas, o que acaba por agravar a sensação de insegurança e incertezas, e até mesmo rejeição, marcantes principalmente nos primeiros meses de adaptação (MORAIS E SILVA, 2010).

Por outro lado, há quem aponte o sotaque como uma forma de evitar a discriminação, na medida em que o status de estrangeiro em determinadas situações garante mais respeito e mesmo alguns privilégios em relação aos negros brasileiros. No entanto, como aponta Silva (2010, p.16):

Se o fato dos acadêmicos africanos serem estudantes de universidades
reconhecidas e de serem estrangeiros confere certo capital simbólico que pode
ajudar a relativizar as intervenções discriminatórias, a percepção sobre o
continente africano arraigada no imaginário brasileiro não permite que a
relativização se complete.

Esta expectativa das autoridades no que diz respeito ao retorno imediato dos estudantes ao fim do curso, bem como a ausência de espaços que evoquem a "África", também são apontadas por Morais e Silva (2010) como um fato agravante da sensação de serem permanentemente lembrados da condição de imigrantes.

Muitas vezes os problemas acima relatados são minimizados, quando o estudante já possui, antes de sua viagem ao Brasil alguma rede de conhecidos ou de contatos, uma rede de sociabilidade com outros africanos ou mesmo com os brasileiros. Outras vezes, estas redes vão vol.09, nº. 02, Rio de Janeiro, 2016. pp. 
sendo construídas na própria vivência do estudante em

${ }^{31}$ É fundamental ressaltar que estudantes provenientes destes países muitas vezes vivem em seus países de origem contextos multilinguísticos, sendo que o português não é, necessariamente, sua primeira língua. Em Moçambique, por exemplo, lista-se 43 idiomas, das quais 41 de origem bantu e 22 reconhecidas pelo estado, sendo apenas um quarto da população de fato falante do português. Da mesma forma, em Cabo Verde, prevalece o crioulo, sendo que em cada uma das dez ilhas que formam o país, fala-se um crioulo diferente. Fica claro que o pluralilsmo linguístico deve ser compreendido como uma complexa questão ao se analisar a formação dos estudantes, entretanto, para os fins do presente artigo, não se pretende entrar nesta questão, mas apenas apontar as dificuldades relatadas no processo de integração dos estudantes africanos no Brasil. Fonte: < http://www.ethnologue.com/>, acessado em 25/07/2012. 
seus espaços cotidianos. São redes configuradas em diferentes instâncias, oficiais e não oficiais, públicas e privadas, de natureza familiar, religiosa ou outras, de diversos contextos nacionais, étnicos e tribais. Segundo Gusmão, "todos os que migram para estudar, de diferentes modos encontram apoios e subsídios entre grupos formais e informais que atuam nos países de origem e nos países de acolhimento" (2008b, p.10)

É destacado em muitos trabalhos que há uma tendência dos africanos se relacionarem mais profundamente entre si, mais especificamente com outros da mesma nacionalidade não apenas para dividir moradias - uma minoria mora sozinha - mas para estabelecer relações afetivas e sexuais, assim como para compartilhar momentos de lazer (Morais e Silva, 2010). Mungoi (2004) aponta para a dificuldade que alguns africanos têm de se aproximar de brasileiros, por considerarem que estes são muito fechados. De toda forma, não se ignora nem se desvaloriza a vivência com estudantes de outras nacionalidades, tendo em vista que, nestes casos, pode-se desfrutar de uma troca muito mais intensa de experiências culturais diferentes.

A partir da construção dessas redes de sociabilidade, muitas são as opções de lazer que se apresentam dentro da comunidade de estudantes africanos no Brasil (GUSMÃO, 2011). As festas são espaços de integração e, ao mesmo tempo, e espaços de auto-afirmação a partir da diferença. Nas palavras de Subuhana (2009, p.119):

Falar de festas é falar de identidade. Elas nos revelam com quem essa população anda e nos mostram como é que essa geração preserva as tradições dos países de origem. [...]. Nessas festas é na comida, nos pratos típicos, como mukapata (Moçambique), cachupa (Cabo Verde), por exemplo, que essa geração deixa transparecer a preservação das tradições africanas: na roupa e na música não tanto.

Pedro (apud GUSMÃO, 2011, p.198) afirma que as festas "são o pivô de articulação dos diferentes grupos dentro do processo de integração". É neste espaço que, além de rever amigos, conhecer novas pessoas, estreitar laços de amizades, estudantes africanos podem comer comidas típicas, usar roupas e penteados típicos sem se destacarem demais, ou ser alvo de observações constrangedoras (de reprovação ou estranhamento/exotismo) e, por isso mesmo, as festas acabam sendo um importante momento de afirmação identitária e coletiva enquanto comunidade africana, como se referem ao coletivo de estudantes (GUSMÃO, 2011).

Estas festas visam, de alguma forma, recriar um "mundo africano", se caracterizando por uma inversão dos papéis de anfitrião/convidado entre os africanos e os brasileiros. Entretanto, além de integrarem a comunidade, estas festas também revelam tensões e competições entre determinados grupos de estudantes africanos (MUNGOI, 2004). Seguindo a linha do raciocínio ambivalente, estas "festas também revelam as razões pelas quais não se vol.09, nº. 02, Rio de Janeiro, 2016. pp. 
configura entre estudantes, uma comunidade africana, ainda que assim se refiram a si mesmos, principalmente, quando buscam afirmar quem são perante os brasileiros" (GUSMÃO, 2011, p.198). Ao mesmo tempo que se forma um espaço em que estes estudantes se sentem mais confortáveis, forma-se nestes eventos uma divisão entre grupos internos de estudantes de etnias diferentes. 
Como colocado por Gusmão (2011), o contexto de estar fora do lugar, ser negro africano e viver a diáspora é constituído pela marca da presença e pela marca da invisibilidade. Mourão (2011) ressalta que é o próprio contexto de transitoriedade vivido por estes imigrantes que faz com que eles se identifiquem, em grupo, como uma comunidade: a "comunidade africana", de maneira mais geral e de forma a amenizar as diferenças étnicas e nacionais, ou, mais especificamente, "comunidade angolana", "comunidade cabo-verdiana", "comunidade guineense", dentre outras, de forma a ressaltar suas especificidades a partir do contraste.

Isso não quer dizer que as diferenças de nacionalidade, de etnia, de crença religiosa, de opção partidária e outras gestadas no mundo africano, se esvaiam em definitivo. Pelo contrário, os próprios sujeitos ao falarem da vida que se vive na terra brasileira, de como se unem e de como se distanciam nas singularidades de suas histórias pessoais e coletivas, nas histórias das muitas Áfricas que o brasileiro desconhece revelam os pontos que marcam os modos de se ser e se estar no Brasil. (GUSMÃO, 2011, p.195)

A perceptível ausência de negros em determinados espaços da sociedade brasileira, em especial no ensino superior, leva à desconstrução do imaginário de que o país vive na chamada "democracia racial". "Vivem, portanto, entre seus colegas da lida universitária e na sociedade, a contradição de serem negados pela cor e positivados pela origem, e no jogo dessa ambivalência, constroem estratégias para agirem no cotidiano” (GUSMÃO. 2008b, p.297).

De acordo com Subuhana (2009, p.121): "o viver fora do país de origem parece reavivar a necessidade de não perder as tradições culturais de origem e de pertença, ao mesmo tempo que cada estudante se transforma em um ser globalizado e parte de um mundo moderno". E continua: "o desenrolar da pesquisa me fez crer que não só existe uma circularidade nos projetos desses estudantes, como também se manifesta a vontade de preservar a herança cultural, através da manutenção de hábitos culinários e estéticos” (2009, p.124).

Mungoi (2004) corrobora essa ideia, ao afirmar que a identidade, ou ainda, a africanidade é reforçada tanto ideológica quanto materialmente: há uma exaltação a elementos considerados africanos (línguas, comidas, penteados, roupas, ideias, religiões, entre outros) e é sobretudo com base nestes elementos que os estudantes se identificam e são identificados como africanos.

OS DIREITOS HUMANOS COMO GRAMÁTICA DE RESISTÊNCIA: UMA PROPOSTA PARA O ENFRENTAMENTO DO PROBLEMA DA IMIGRAÇÃO AFRICANA NO BRASIL 
Observamos acima algumas das dificuldades enfrentadas por esse contingente, o que nos leva a verificar que, além dos problemas relacionados à auto-estima, os estudantes africanos têm que lidar também com desafios para a conformação do autorrespeito. Negar-lhes as pretensões jurídicas socialmente vigentes significa lesar suas 
expectativas intersubjetivas de serem reconhecidos como sujeitos capazes de formar juízo moral. A partir da perspectiva da Teoria do Reconhecimento, como já desenvolvido, é possível afirmar que a real fruição de direitos pode indicar o desenvolvimento da esfera de autorespeito desses indivíduos.

Diante da situação de desrespeito e invisibilidade a que são submetidos os africanos no Brasil, as opções teórico-jurídicas para seu enfrentamento devem passar necessariamente pela busca da emancipação e do reconhecimento. Acredita-se que pela via dos direitos humanos podem ser pensadas e implementadas políticas públicas nesse sentido. No entanto, para que a aposta nos direitos humanos se converta na construção de uma sociedade mais equânime, tolerante e justa é preciso desmistificar certos pressupostos e enfrentar os paradoxos gerados por uma abordagem não comprometida com o respeito a seres concretos e plurais.

Visões críticas $^{32}$ acerca dos direitos humanos mostraram, com bastante competência, que eles foram sistematicamente usados para mascarar e naturalizar situações de dominação e opressão e garantir, através da falácia de sua universalidade, as condições necessárias para o desenvolvimento do modelo capitalista, por definição desigual e excludente.

Salta aos olhos a "tragédia do homem contemporâneo enfrentando um mundo que se lhe opõe ferozmente e frente ao qual a impotência, a inação, o isolamento, a loucura e, talvez, a ironia, constituem as únicas armas 'reais' de que pode dispor" (HERRERA FLORES, 2007, p.108). A cruel realidade que desumaniza todos aqueles que fogem à condição de Sujeito de direitos humanos e a constatação de que as grandes declarações de direitos cumpriram o papel de manutenção e legitimação dessa mesma ordem, levou-nos a buscar na teoria do reconhecimento, tal como descrita por Honneth, uma gramática alternativa para esses direitos.

Quando afirma que a tensão afetiva gerada pelo sofrimento humano força o indivíduo a se insurgir contra a realidade que o oprime, Honneth vai desmistificar a tese de que os 'inumanos' experienciam com neutralidade e passividade as violências sofridas. Essa constatação auxilia a reconstrução da dogmática dos direitos humanos a partir de um ideário dos conflitos e da resistência política: "Quando a intransponibilidade do abismo entre as declarações missionárias sobre igualdade e dignidade, e a realidade sombria da desigualdade obscena se tornam aparentes, os direitos humanos - ao invés de eliminar a guerra - levarão a novos e incontroláveis tipos de tensão e conflito" (DOUZINAS, 2009c).

No lugar de ideias que escamoteiam a realidade e retiram da esfera do político as instituições centrais do capitalismo global neoliberal, a dimensão do político é reabilitada e 
radicalizada. Ao invés de um eficiente depósito de rancor, um inesperado laboratório de resistência.

${ }^{32}$ De acordo com Douzinas (2009 c) Marx foi o primeiro a denunciar que os direitos naturais surgiram como
poderosa arma nas mãos da classe capitalista em ascensão, instituições assegurando e naturalizando relações
sociais e econômicas dominantes. "Eles foram usados para retirar do desafio político as instituições centrais do
capitalismo, como a propriedade, as relações contratuais, a família, a religião". 
Quando se encara os direitos humanos como gramática dos conflitos, pode-se ressignificar algumas práticas de resistência empreendidas por imigrantes e que são tratadas, na maioria das vezes, como práticas extremadas. Incêndios a bens materiais, ocupação de prédios públicos e manifestações políticas de diversas naturezas nada mais refletem do que o inconformismo sentido por qualquer pessoa submetida a um falso ou à falta de reconhecimento.

A resistência à naturalização de uma imagem depreciativa imposta a si mesmo e às condições de vida subumanas só se configura como padrão de 'civilidade' se realizada por Sujeitos reconhecidos como tais. Ao contrário, se o autor da resistência é alguém cuja imagem social é vinculada a estereótipos de atraso e subdesenvolvimento, a resistência é entendida e tratada como baderna, vandalismo, selvageria e inadaptação a uma sociedade 'livre'.

A cultura não deve ser vista como desconectada das estratégias de ação social. Ela responde contextualmente à maneira pela qual são determinadas as relações sociais, econômicas e políticas. Dessa estreita interconexão entre problemas culturais, sociais, econômicos e políticos propõe-se uma visão complexa dos direitos humanos. Uma visão que assume a realidade e a presença de múltiplas vozes, todas com o mesmo direito a expressar-se, a denunciar e exigir e a lutar (HERRERA FLORES, 2004). Uma visão que entende os direitos humanos com produtos culturais.

Assim como a teoria do reconhecimento complexifica a noção de direitos humanos, tem sua dimensão ampliada pela nova conformação proposta. Se reabilitado o caráter emancipatório do direito, a resposta normativa ao reconhecimento passa a ser alargada, atuando não apenas na esfera do autorespeito, mas também nos contornos da estima social:

O reconhecimento outorgado pelos direitos humanos não se estende apenas a objetos externos, tais como a propriedade e as prerrogativas contratuais. Ele chega ao âmago da existência, aborda a fundamental apreciação do Outro e a autoestima do indivíduo além do respeito, e toca as bases de sua identidade. Esse tipo de reconhecimento concreto não pode estar baseado em características universais da lei, mas em uma luta contínua pelo desejo singular do Outro e seu concreto reconhecimento. Os direitos humanos, como o desejo, constituem um campo de batalha com uma dimensão ética. (DOUZINAS, 2009, p. 293)

Para promover uma relação de respeito mútuo entre imigrantes e grupos culturais existentes no país de destino, deve-se escapar das armadilhas do universalismo abstrato (e sua racionalidade jurídico/formal) ou do comunitarismo (e sua racionalidade material/essencialista) e partir para a afirmação dos direitos humanos enquanto racionalidade de resistência. ${ }^{33}$ 
33 "O que negamos é considerar o universal como um ponto de partida ou um campo de desencontros. Ao universal há de se chegar

- universalismo de chegada ou de confluência - depois (não antes) de um processo conflitivo, discursivo de diálogo ou de confrontação" (FLORES, 2004, pg. 375). Assim como Herrera Flores, Douzinas mostra a insuficiência das respostas universalistas e comunitaristas para a temática dos direitos humanos. De acordo com o autor (DOUZINAS, c) tanto universalistas quanto comunitaristas tomaram uma decisão axiomática em relação àquilo que constitui a essência da humanidade e a seguem com um 
Herrera Flores propõe um universalismo impuro que pretende não a superposição, mas o entrecruzamento. Uma proposta que não é universalista nem particularista, mas intercultural, ${ }^{34}$ cujo único essencialismo válido é o de "criar condições para o desenvolvimento das potencialidades humanas, o de um poder constituinte difuso que faça a contraposição, não de imposições ou exclusões, mas de generalidades compartidas às que chegamos (de chegada), e não a partir das quais partimos (de saída)” (2004, p. 375).

Sem a ideia de entrecruzamento cultural corre-se o risco de reprodução da ideologia dominante dos impérios, imperialismos e colonialismos ocidentais. Nessa lógica, o Outro é inumano ou subumano, o que justifica a escravidão, as atrocidades e até a aniquilação como estratégias da missão civilizatória e de sua integração à ideia de 'humanidade'. No diálogo intercutural, as provisões abstratas dos direitos podem sujeitar as desigualdades e indignidades a um ataque contundente (DOUZINAS, 2009c).

O terreno sobre o qual se trabalha é arenoso, se a busca for por estabilidade e segurança a contribuição será de pouca valia. Aliando a teoria do reconhecimento de Honneth e a noção de direitos humanos de Douzinas e Herrera Flores, intenta-se reconhecer que os direitos humanos escondem e afirmam a estrutura dominante, mas busca-se enfatizar que eles revelam a desigualdade, a invisibilidade, a opressão e o desrespeito e ajudam a desafiá- los.

Essa proposta pode ser sistematizada pelo seguinte axioma proposto por Douzinas (2009c): "O objetivo dos direitos humanos é de resistir à dominação e à opressão pública e privada. Eles perdem este objetivo quando se transformam em ideologia política, ou em idolatria do capitalismo neoliberal ou na versão contemporânea da missão civilizatória”.

Enquanto gramática de resistência, é preciso tomar os direitos humanos nas mãos, encarar os vários rostos de seus sujeitos, empoderar-se mutuamente e construir as condições necessárias para que as experiências se constituam em luta permanente pela dignidade. Herrera Flores os conceitua a partir do universo normativo de resistência como:

produtos culturais que formam parte da tendência humana ancestral por construir e assegurar as condições sociais, econômicas, políticas, econômicas e culturais que permitem aos seres humanos perseverar na luta pela dignidade, ou o que é o mesmo, o impulso vital que, em termos spinozanos, lhes possibilita manter-se na luta por seguir sendo o que são: seres dotados de capacidade e potência para atuar por si mesmos. (2009, p.191)

Deve-se renunciar a ideias de conquistas acabadas e entendê-los como processos de afirmação da dignidade: “os direitos humanos são os meios discursivos, expressivos e 
normativos que pugnam por reinserir os

“teimoso desrespeito aos argumentos contrários”. Em sua perspectiva, a humanidade não pode atuar como um princípio normativo, niilista ou mitológico; ela não é uma propriedade compartilhada, não tem fundamento, tampouco fim.

${ }^{34}$ Para Herrera (2004) reivindicar a interculturalidade não se limita no necessário reconhecimento do outro. É preciso transferir poder, 'empedrar' aos excluídos dos processos de construção de hegemonia. 
seres humanos no circuito de reprodução e manutenção da vida, permitindo-lhes abrir espaços de luta e de reivindicação" (HERRERA FLORES, 2004, p.382).

Enquanto houver relações de servidão, dominação, opressão e violência, haverá o desejo por uma liberdade positiva e uma fraternidade emancipatória. Essa tensão deve alimentar a ação política das classes domésticas e civilmente subalternas para invenção de um novo mundo e as empurrará para construção das condições necessárias para chegar a ele. Essa concepção impõe o redimensionamento não apenas do que se convencionou entender como direito humano, como de todos os pressupostos de sua realização: "os direitos humanos podem voltar a re-clamar o seu papel redentor nas mãos e imaginação de quem os devolvem à tradição de resistência e luta, contra o conselho dos pregadores do moralismo, da humanidade sofredora e da filantropia humanitária” (DOUZINAS, 2009c)

Busca-se um outro direito, a abertura de novos espaços de construção coletiva da subjetividade e cidadania, e, uma outra forma de divisão do fazer que permita o acesso igualitário às condições que dão dignidade.

A partir dos espaços de luta, o indivíduo luta pelo que é seu, quer dizer, pela sua capacidade de atuar em prol de uma vida digna, e não renuncia ao que não tem (seus pretendidos direitos), ou seja, de sua capacidade e sua potencialidade humana para assumir, impor e garantir política, econômica, social, cultural e juridicamente compromissos e deveres que nos responsabilizem e, ao mesmo tempo, responsabilizem as instituições públicas e privadas na construção das condições para aceder igualitariamente aos bens necessários para a vida. (HERRERA FLORES, 2009, p. 203)

Nesse sentido, para enfrentar o problema da interação dos imigrantes africanos no Brasil, propõe-se esse enfrentamento constante, do qual florescerão universos simbólicos plurais e interativos, práticas sociais antagonistas às ordens hegemônicas monoculturais, políticas públicas definidas democraticamente e comprometidas em dar respostas a necessidades humanas concretas e agendas políticas alternativas.

\section{CONCLUSÃO}

Este artigo se propôs a analisar a situação dos estudantes africanos no Brasil à luz da Teoria do Reconhecimento de Honneth e de um conceito emancipatório dos direitos humanos. A partir das principais contribuições teóricas acerca do debate sobre reconhecimento pretendeuse defender uma concepção dos direitos humanos como resistência e emancipação. Através de 
$\overline{\text { ideias como 'identidade' e 'autenticidade', buscou- se afirmar a singularidade do sujeito e }}$ confrontar o universalismo abstrato dos direitos humanos, no que diz respeito à questão migratória. O reconhecimento enquanto necessidade humana vital ressalta a importância do Outro para a conformação sadia das Identidades. 
Inicialmente, o trabalho desenvolveu as ideias de identidade e autenticidade, centrais para entender a categoria do reconhecimento. Em seguida, passou-se à determinação dos principais pressupostos sobre os quais se sustenta a Teoria do Reconhecimento, com destaque para a análise empreendida por Axel Honneth na obra Luta por reconhecimento (2003).

Uma vez definido o marco teórico da luta por reconhecimento, realizou-se uma análise da situação dos estudantes africanos no Brasil. Para, em seguida, cotejar as contribuições de Joaquín Herrera Flores e Costas Douzinas na busca de uma concepção de direitos humanos comprometida com o respeito ao Outro e com o desenvolvimento sadio das diversas subjetividades.

Em lugar da suposta neutralidade da legislação nacional nessa matéria, aparece um modelo jurídico seletivo e incapaz de absorver e de lidar, com igual estima e consideração, com identidades plurais e formas de vida diversas. Em caráter provisório os Outros são aceitos, mas para que saiam da condição de provisórios e integrem- se definitivamente ao âmbito de proteção brasileira, é preciso que se apresentem como ou que se aproximem do padrão normalizado de Sujeito de direito.

A língua normalmente é colocada como um dos principais elementos de integração entre pessoas de nacionalidades distintas. A despeito deste fato, mesmo os estudantes angolanos, caboverdeanos e guiné- bissauenses, que comungam com os brasileiros a mesma origem linguística e colonial, sofrem no processo de 'integração', o que nos leva a crer que ela possa estar calcada em outros critérios. A diferença de valores, crenças e costumes resultam em uma significativa discrepância na significação e na produção cultural. Quando confronta-se pessoas que compartilham uma forma de vida comunitária, apegada a valores tradicionais, com os valores patriarcais, eurocêntricos, individualistas, capitalistas, heteronormativos e cristãos que é naturalizado por aqui, mais marcada fica a distância entre nós.

Ao invés de um diálogo intercultural que permita a sobrevivência das diversas identidades e o respeito às várias subjetividades, tem-se um pernicioso filtro hierarquizante de seres humanos que mutila identidades, como forma de garantir a mínima fruição de direitos. Diante da relação inexorável entre identidade e reconhecimento, destaca-se a proposta de Axel Honneth para uma vinculação mais estreita entre teoria do reconhecimento e direito. A partir da constatação de que os seres humanos, e nesse artigo especificamente os imigrantes, não podem se comportar de maneira neutra e passiva em relação às ofensas sociais ou à privação de direitos, os direitos humanos deixam de se constituírem em um eficiente depósito de rancor, dando lugar a 
Quaestio Iuris

um laboratório de resistência. vol. 09, n. 02, Rio de Janeiro, 2016. pp. $757-787$ 


\title{
AFRICAN IMMIGRANTS IN BRAZIL FROM THE PERSPECTIVE OF THE CRITICAL THEORY OF HUMAN RIGHTS
}

\begin{abstract}
The purpose of this paper is to analyze the situation of African students in Brazil according to the Theory of Recognition of Honneth and to an emancipatory concept of human rights. From the major theoretical contributions on the debate about recognition it is intended to build a conception of human rights as resistance and emancipation. Firstly, from the ideas of 'identity' and 'authenticity', the singularity of the individuals is affirmed against the abstract universal concept of human rights. Recognition as a vital human need emphasizes the importance of the Other to a nourishing conformation of Identities. Facing the inexorable relationship between identity and recognition, we make reference to Axel Honneth's assumption, which evidences the strict connection between the theory of recognition and rights. Based on the concept that human beings, and in this article specifically immigrants, may not behave neutrally or passively towards social offenses or deprivation of rights, human rights cease to constitute an efficient deposit of resentment, leading to a laboratory of resistance.
\end{abstract}

Keywords: Human Rights; Immigration; Africans; Brazil; Theory of Recognition.

\section{REFERÊNCIAS BIBLIOGRÁFICAS}

AVRITZER, Leronardo. "Em busca de um padrão de cidadania mundial". Lua Nova, no 55-56, pp. 29-55.2002.

BATISTA, V. O. "O fluxo migratório mundial e o paradigma contemporâneo de segurança migratória”. Revista Versus, v.3. 2009.

BATISTA, V. O., BOITEUX, L., PIRES, Thula Rafaela. Direitos Humanos. Brasília: Secretaria de Assuntos Legislativos do Ministério da Justiça (SAL). 2009.

BOBBIO, Norberto. A Era dos Direitos. Rio de Janeiro: Campus, 1992.

CAVARZERE, Thelma Thais. Direito Internacional da Pessoa Humana. A Circulação Internacional de Pessoas. 2 ed. Rio de Janeiro/São Paulo, 2001.

COHEN, Jean. "Changing Paradigms of Citizenship and the Exclusiveness of the Demos". International Sociology, vol 14, n. 3, pp. 245-268. 1999.

COMPARATO, Fábio Konder. A Afirmação Histórica dos Direitos Humanos. São

Paulo: Saraiva, 1999. DALLARI, Dalmo de Abreu. Direitos Humanos e Cidadania. São

Paulo: Editora Moderna, 1998.

DOUZINAS, Costas. O fim dos direitos humanos. Trad. Luzia Araújo. São Leopoldo: Unisinos, vol.09, nº. 02, Rio de Janeiro, 2016. pp. 


\section{9 .}

Quem são os "humanos" dos direitos? 2009a. Disponível em 〈http://revolucoes.org.br/v1/sites/default/files/quem_sao_os_humanos_dos_direitos.pdf〉, acesso em 14 de abril de 2011. mimeo. 


\section{Que são direitos humanos? 2009b. Disponível em}

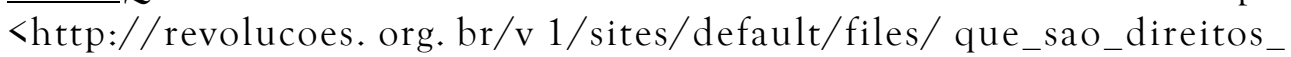

humanos. pdf $>$, acesso em 14 de abril de 2011. mimeo.

Os paradoxos dos direitos humanos. Trad. Caius Brandão.

2009c. Disponível em

<http://revolucoes.org.br/v1/sites/default/files/o_paradoxo_dos_direitos_humanos.pdf>, acesso em 14 de abril de 2011. mimeo.

Entrevista com Costas Douzinas 2009d. Disponível em

<http:// revolucoes. org. br/v 1/sites/default/files/ educacao_revolucoes_ e_seus_direitos

_entrevista_com_costas_douzinas.pdf $>$, acesso em 14 de abril de 2011.mimeo.,

FERNANDES, Rubem Cesar. "Elos de uma Cidadania Planetária". Revista Brasileira de Ciências Sociais, n 28, pp. 15-34. 1995.

GHAI, Yash. "Globalização, multiculturalismo e direito". In SANTOS, Boaventura de Sousa. Reconhecer para Libertar: os caminhos do cosmopolitismo multicultural.capítulo 12. Rio de Janeiro: Civilização Brasileira, pp. 555- 614. 2003.

GUARNIZO, Luis Eduardo. "The Economics of Transnational Living”, International Migration Review, vol. 37, n. 3, pp. 666-699. 2003.

GUARNIZO, Luis Eduardo; PORTES, Alejandro; HALLER, William J. “Assimilation and Transnationalism Determinants of Transnational Political Action among Contemporary Immigrants”, American Journal of Sociology, vol. 36, n.3, pp. 766-799. 2003.

GUSMÃO, Neusa Maria Mendes de. "Na Terra do Outro": presença e invisibilidade de estudantes africanos no Brasil, hoje”. Dimensões, vol. 26, p. 191-204. 2011.

"Diáspora africana: a vida de imigrantes e estudantes em Portugal e no Brasil". Trabalho apresentado na 26a Reunião Brasileira de Antropologia, Porto Seguro, 2008a.

"África e Brasil no mundo acadêmico: diálogos cruzados". Trabalho apresentado no Colóquio Saber e Poder, Focus, Unicamp, 2008b.

HABERMAS, Jürgen. Pensamento pós-metafísico: estudos filosóficos. Rio de Janeiro: Tempo Brasileiro, 1990.

HERRERA FLORES. Joaquín. Teoria Crítica dos Direitos Humanos: os direitos humanos como produtos culturais. Rio de Janeiro: Lumen Júris, 2009.

(2007), O nome do riso: breve tratado sobre arte e dignidade. Tradução de Nilo Kaway Junior. Florianópolis: CESUSC, 2007.

(2004), "Direitos Humanos, Interculturalidade e Racionalidade de Resistência". In Direitos Humanos e Filosofia Jurídica na América Latina. Antonio Carlos Wolkmer (Org). cap. 11. Tradução de Carol Proner. Rio de Janeiro: Lumen Júris, pp. 359-385. 2004.

HONNETH, Axel. Luta por Reconhecimento: a gramática moral dos conflitos sociais. Tradução de Luiz Repa.São Paulo: Ed. 34, 2003 a. 2003b.

Redistribution or recognition? A political philosophical exchange. London: Verso,

Freedom's right: the social foundations of Democratic life. Translated by Joseph Ganahl. vol.09, nº. 02, Rio de Janeiro, 2016. pp. 
New York: Columbia University Press, 2014.

HUNT, Lynn. A Invenção dos Direitos Humanos. Uma história. São Paulo, Companhia das Letras, 2009. 
KALY, Alain Pascal. "Os Estudantes Africanos no Brasil e o Preconceito Racial” In CASTRO, Mary Garcia (coord.). Migrações Internacionais: Contribuições para Políticas, Brasil 2000. Brasília: CNPD. p. 463-478. 2001.

LAFER, Celso. A Reconstrução dos Direitos Humanos: um diálogo com o pensamento de Hannah Arendt. São Paulo: Companhia das Letras, 1988.

LEVITT, P., GLICK SCHILLER, N. "Conceptualising simultaneity: a transnational social field perspective on society”, International Migration Review, vol. 38, n. 3, pp. 1002-1039. 2004.

MATTOS, Patrícia. "O reconhecimento social e sua refundação filosófica em Charles Taylor". In Teoria Crítica no século XXI. Jessé Souza e Patrícia Mattos (Org.). São Paulo: Annablume, 2007.

MELLO, Celso D. de Albuquerque. Curso de Direito Internacional Público. Rio de Janeiro: Renovar, 2004.

MORAIS , Sara Santos ; SILVA, Kelly Cristiane da. "Estudantes de países africanos de língua oficial portuguesa nas universidades brasileiras: tensões de sociabilidade e dinâmicas identitárias". Trabalho apresentado na 27ª Reunião Brasileira de Antropologia, Belém, 2010.

MOUFFE, Chantal. "Democratic Citizenship and the Political Community". In MOUFFE, C. (ed.) Dimensions of Radical Democracy: Pluralism, Citizenship, Community. London: Verso, 1992.

MOURÃO. Daniele Ellery. "Cabo Verde, Guiné-Bissau, Brasil: Saudade e festa como reconstrução e afirmação de elos afetivos”. Revista Brasileira de Sociologia da Emoção, vol. 10, no29, pp. 256-273. 2011.

MUNGOI, Dulce Maria Domingos Chale João. "O Mito Atlântico": relatando experiências singulares de mobilidade dos estudantes africanos em Porto Alegre no jogo de reconstrução de suas identidades étnicas. (Dissertação de Mestrado) UFRGS: Porto Alegre, 2004.

PEREIRA, Glória Maria Santiago; BIZERRIL, José. "Refugiados no Brasil: Identidade e Subjetividade”. Trabalho apresentado no XVI Encontro Nacional de Estudos Populacionais, Caxambu, 2008.

PIOVESAN, Flavia. Direitos Humanos e justiça internacional: um estudo comparativo dos sistemas regionais europeu, interamericano e africano. São Paulo: Saraiva, 2006.

Temas de Direitos Humanos. 3ª ed. São Paulo: Saraiva, 2009.

PORTES, Alejandro. "Convergência teórica e dados empíricos no estudo do transnacionalismo imigrante”. Revista Crítica de Ciências Sociais, n. 69, pp. 73-93. 2004

PREUSS, Ulrich K. "Migration - a Challenge to Modern Citizenship". Constellations, v. 4, Number 3.2008 RAMOS, André de Carvalho. Processo Internacional de Direitos Humanos. Rio de Janeiro: Renovar, 2002. 
SANTOS, Boaventura de Sousa. Reconhecer para libertar: os caminhos do cosmopolitismo multicultural. Rio de Janeiro: Civilização Brasileira, 2003.

SAYAD, Abdelmalek. A Imigração ou os Paradoxos da Alteridade. Prefácio de Pierre Bordieu; tradução de Cristina Murachco. São Paulo: Editora da Universidade de São Paulo, 1998. 
SEMPRINI, Andréa. Multiculturalismo. Tradução: Laureano Pelegrin. São Paulo: EDUSC, 1999.

SILVA, Anso da. "A Experiência Dos Alunos Africanos Nas IES No Brasil: O Caso De MS".

Trabalho apresentado na 27․ Reunião Brasileira de Antropologia, Belém, 2010.

SOUZA, Jessé. A Construção social da subcidadania. Para uma Sociologia Política da

Modernidade Periférica. Rio de Janeiro: IUPERJ, 2003.

Pierre Bourdieu: pensador da periferia? In Teoria Crítica no século XXI. Jessé Souza e

Patrícia Mattos (Org.). São Paulo: Annablume, 2007.

SOUZA, Lorena Francisco de. "Migrações Na Sociedade Moderna: O Caso Dos Estudantes Africanos No Brasil". Trabalho apresentado no XI Congresso Luso Afro Brasileiro de Ciências Sociais, Salvador, 2010.

SOYSAL, Y. Limits of Citizenship. Chicago: University of Chicago Press, 1994.

SUBUHANA, Carlos. A experiência sociocultural de universitários da África Lusófona no Brasil: entremeando histórias. Pro-Posições, Campinas, v. 20, n. 1, pp. 103-126. 2009.

TAYLOR, Charles Taylor. El multiculturalismo y "la política del reconocimiento". Tradução de Mónica Utrilla de Neira. México: Fondo de Cultura Económica, 2001.

As Fontes do Self - a construção da identidade moderna. São Paulo: Edições Loyola, 1997.

La ética de la autenticidad, Barcelona: Paidos, 1994.

UNDP (2010). Mobility and Migration: A Guidance Note For Human Development Report Teams. Nova York: United Nations Development Programe, Human Development Report Office.VERTOVEC, Steven, "Migration and Other Modes of Transnationalism". International Migration Review, vol. 37, n. 3, pp.641-665. 2003.

VIDA, Samuel Santana. "Africanos no Brasil: uma ameaça ao paraíso racial”, in CASTRO, Mary Garcia (coord.). Migrações Internacionais: Contribuições para Políticas, Brasil 2000. Brasília : CNPD, 2001.

VIEIRA, Liszt. Cidadania e Globalização. Rio de Janeiro: Editora Record,

1997. VILLEY, Michel. O direito e os direitos humanos. São Paulo:

Martins Fontes, 2007.

WALDINGER, Roger. "Rethinking Transnationalism”. EMPIRIA - Revista de Metodología de Ciencias Sociales, n. 19, pp. 21-38. 2010

SANTOS, Wanderley Guilherme dos. Cidadania e justiça. Rio de Janeiro: Campus, 1979.

Trabalho enviado em 18 de setembro de 2015.

Aceito em 06 de janeiro de 2016. 